Article

\title{
The Rise of Border Areas in an Integrated Region of China
}

\author{
Minsheng Li ${ }^{1}$, Haohui Chen ${ }^{2, *(\mathbb{C}, \text { Yaofu Huang }}{ }^{3}$ and Meiyu Huang ${ }^{1}$ \\ 1 Urban and Rural Planning and Design Institute, Sun Yat-sen University, Guangzhou 510275, China; \\ gpp04lms@mail3.sysu.edu.cn (M.L.); huangmyu@mail3.sysu.edu.cn (M.H.) \\ 2 Data61, Commonwealth Scientific and Industrial Research Organization, Docklands VIC 3008, Australia \\ 3 School of Geography and Planning, Sun Yat-sen University, Guangzhou 510275, China; \\ hyaofu@mail2.sysu.edu.cn \\ * Correspondence: caronhaohui.chen@data61.csiro.au
}

Received: 9 August 2019; Accepted: 8 October 2019; Published: 15 October 2019

check for updates

\begin{abstract}
Increasing economic integration between countries has spurred the rapid growth of border areas. However, whether city-level boundary areas can benefit from regional integrations within one regime is unknown. Along with growing numbers of integrated regions in developing economies, especially in China, understanding the extent to which geographic growth and location conditions play roles in the process is of great importance. Therefore, this study used night-time light data between 2013 and 2018 to investigate the growth patterns of different parts of the highly integrated Pearl River Delta (PRD) of China. The results showed that border areas, especially those with emerging economies, grew faster than city centers during the study period. Moreover, we built ordinary least square (OLS) regression and spatial econometrics models to understand how location conditions across the two cities affected the growth process. The models showed that the urbanization levels across the two cities had inverted U-shaped effects on the growth of border areas. The social security costs also exhibited negative effects. The study findings can help policymakers better understand emerging growth areas and, accordingly, deploy appropriate policies to overcome the obstacles to the integration process and ensure equity in development opportunities.
\end{abstract}

Keywords: regional integration; border areas; location conditions; pearl river delta; night-time light

\section{Introduction}

Regional integration plays an increasingly important role in narrowing the economic gap between developed and developing economies [1-4]. By eliminating trade barriers [5], promoting technology transfer [2], and developing transportation infrastructure [6], integrated regions gain global competition through industrial relatedness [7] and agglomerated human capital [8,9]. Over the last three decades, the Chinese government has been promoting regional integration as a national policy to develop economies and mitigate regional inequality [9-13]. Accordingly, 12 integrated regions have emerged [14]. Among them, the Yangtze River Delta, Beijing-Tianjin-Hebei, and Pearl River Delta (PRD) generated a gross domestic product (GDP) of 17,864.2, 8758.2, and 8104.9 billion RMB in 2018, respectively, and accounted for more than $38 \%$ of China's total GDP. All those integrated regions have allowed China to develop competitive advantages in a large number of sophisticated products, including machinery, chemicals, and capital-intensive products that represent the industrial level of an economy but used to be dominated by developed economies [14]. Therefore, integrated regions have been crucial to China's economic development.

The border areas have always been regarded as peripheral to their corresponding economies, which explains why they have been marginalized, neglected, and underdeveloped [15]. Although 
areas on both sides of the border have faced similar problems, they have been unable to co-operate because the border has hampered interaction between them. However, the strong surge of cross-border and intra-border regional integration has yielded the rapid growth of border areas. Since the opening of internal borders among European Union (EU)-member countries, a large number of border areas have experienced significant growth. A typical example is the border area between Maribor of Slovenia and Graz of Austria, where new urban nodes along the infrastructural corridor have emerged and now host a negligible number of foreign workers from both countries [16]. Other examples include Germany [17], Hungary [18], France, Switzerland, Greece, Bulgaria, Poland, and Spain [19]. Since the launch of the Mexican Border Industrialization Program, large numbers of manufacturing businesses from the U.S. have been relocated to border regions in Mexico [20]. In addition, intra-border integration has also led to the prosperity of border areas between two states within one country. For example, because of lower taxes and other incentives, border counties in New Jersey have benefited from the relocation of large numbers of firms from New York City and Philadelphia [21]. In China, provincial border regions inside two highly integrated regions, the Yangtze River Delta and Beijing-Tianjin-Hebei, have also been identified as growing more rapidly than other regions [22].

During the process of regional integration, border areas across national or state borders could benefit significantly and experience rapid growth. However, to the best of our knowledge, border areas within the same regime (e.g., the same state or province) have never been studied in the context of regional integration, so the extent to which they could benefit is unknown. Regional integrations have contributed significantly to China's economic growth over the past decades. However, we have a limited understanding of how border areas develop. Therefore, we aimed to study the border areas in an integrated region of China (to be more specific, the areas between municipalities in the PRD) to understand how those areas have developed and how much location conditions across the border affect the process of regional integration.

This study complemented existing research as follows: (i) We took the Pearl River Delta in China as an example, providing a practical example in developing countries for the growth of border areas in integrated regions with the same regime; (ii) Most prior studies on border areas failed to define the specific scope of the boundary, and used qualitative methods to measure the growth of border areas, including the emergence of new functional nodes in the border areas [16], enterprise agglomeration [20,21], and population agglomeration [17]. We specifically defined the geographical extent of the border areas, and used data such as night-time light (NTL) to provide a quantitative measure of growth in the border areas. The spatial distribution of the growth area, the degree of growth, and the factors behind growth were all observed; (iii) The findings of this study can be of significant value to policymakers. On the one hand, there are emerging integrated regions across China and other developing countries; on the other hand, even in well-developed integrated regions, like the Pearl River Delta, there are still significant development gaps across all included municipalities. Understanding the growth of the border areas can help policymakers design and deploy appropriate policies to overcome the obstacles of the integration process and ensure equity in development opportunities.

Growth was an important theme of this research because the uneven distribution of economic activities and resources in space has been shown to lead to different levels of growth in different areas. Research on growth is based on two large groups of theories: location and regional growth theory. The location theory has microeconomic foundations and focuses on how firms and households choose locations under the influence of transportation costs and agglomeration economies; the regional growth theory is macroeconomic. This theory focuses on how effectively and creatively the resources are used to promote the region to play an appropriate role in the international division of labour. Recent research has considered that space is diversified, a notion that emphasizes one of the inspiring principles of location theory: the importance of agglomeration economies. When space is considered to be "diversified-relational", a macroeconomic and macro-territorial approach gives way to a microeconomic and micro-territorial one. Regional growth is actually the result of individual economic actors (e.g., large or small, public and private firms) reconfiguring themselves based on activities, resources, economics, 
and market relationships [23]. Therefore, we believed it was necessary to explain the growth of the border areas from the perspective of firms.

Regarding the factors affecting regional growth, some scholars have emphasized the importance of endogenous factors. Spatial growth is rarely determined by exogenous factors, such as raw materials and natural resources, and is more often determined by endogenous factors, such as human resources, social resources, land productivity, and accessibility [23]. In 2005, the European Commission defined the concept of "territorial capital", arguing that each region has specific territorial capital that is different from that of other regions and generates a higher return by investing in its territorial capital [24]. Territorial capital is considered to be an important driver of regional economic growth $[25,26]$. Different scholars have searched for appropriate indicators for measuring the factors affecting territorial capital [23,27-29]. Seven components of territorial capital have been clearly proposed: economic capital, infrastructural capital, institutional capital, human capital, social capital, relational capital, and cultural capital [28]. In an empirical study of Romania, according to the actual situation of the country and available data, a scholar proved that economic capital, infrastructural capital, institutional capital, and human capital have contributed positively to regional economic growth, whereas social capital has had a negative impact [26]. Based on the actual situation of the Pearl River Delta and the availability of data, economic capital, infrastructural capital, and social capital have been identified as the main aspects explaining regional growth, specifically in the growth of the border areas studied in this research.

Firm relocation activities and resulting employment growth could explain the majority of cases of growing border areas $[8,21,30]$. Location conditions, including transportation, materials, markets, labour, external economies (urbanization and localization), energy, community infrastructure, capital, land/building, and environmental and governmental policy, affect individual firms when choosing the locations for specific factories [30]. In border areas between two different municipalities within the same regime, most of those location conditions have been found to be similar except for labour, urbanization, and government policy (e.g., social security responsibility [31]). If firms could benefit from relocations to border areas where there are significant differences in location conditions, those border areas might undergo rapid growth. Therefore, we introduced our first hypothesis as follows:

Hypothesis 1. In the context of regional integration, border areas within the same province develop faster than city centers or the city as a whole.

If the border areas developed faster than city centers or the city as a whole, we assumed the growth would be heterogeneous in geography, as the process of integration could concentrate on particular parts where the location conditions varied the most. In this regard, the location conditions that were available to us, such as rent costs, wages, and social security responsibilities, could also be tested in terms of their effects on the growth of the corresponding border areas. Therefore, we introduced our second hypothesis as follows:

Hypothesis 2. The differences in location conditions that are relevant to firm relocation between two neighbouring municipalities can significantly affect the growth of the corresponding border areas.

\section{Materials and Methods}

\subsection{The Study Case}

We took the Pearl River Delta as the study area. The Pearl River Delta, located in the Guangdong province of China, is comprised of nine cities: Guangzhou, Shenzhen, Dongguan, Foshan, Zhongshan, Zhuhai, Huizhou, Jiangmen, and Zhaoqing. Since the economic reform and adoption of the open-door policy by China in 1979, production factors such as foreign capital, cheap labour, and land have 
supported the development of the Pearl River Delta for nearly 40 years, making this region representative of a global "growth miracle". The Pearl River Delta has been one of the region's leading economic developments in China. In 2018, the Pearl River Delta, which accounts for less than 6\% of China's land area and $4.5 \%$ of China's population, contributed $9 \%$ of the country's GDP, and its per-capita GDP was twice the national average.

\subsection{Monitoring Economic Growth}

This study used NPP-VIIRS night-time light year data provided by the National Oceanic and Atmospheric Administration (NOAA) to identify economic growth in border areas, city centers, and the city as a whole. Night-time light data are remotely sensed data that can objectively reflect the intensity of economic activity on the Earth's surface, and can overcome the shortcomings of traditional economic census data to a certain extent [32,33]. The NPP-VIIRS was acquired by the first satellite (NPP) sensor of the new generation of the National Polar Orbiting Operational Environmental Satellite System (NPOESS), and its composite image could be generated using night-time data from the visible infrared imaging radiometer suite (VIIRS) day/night band (DNB) [34]. NPP-VIIRS data, at a resolution of 15 arc seconds (about $500 \mathrm{~m}$ ) grids, has a higher spatial resolution and a wider radiometric detection range than DMSP/OLS data, which allows it to more accurately reflect the changes in human activities on the surface $[35,36]$. We screened out the border areas between two cities in the Pearl River Delta by selecting the municipal roads that had been built across the boundaries of every two cities, overlapping the $2000 \mathrm{~m}$ of buffer space from the city administrative boundary. A total of 47 border areas were identified. Taking the towns in each city of the Pearl River Delta as a basic unit, the towns where the population density ranked in the top $10 \%, 20 \%$, and $30 \%$ of the whole city were defined as the city centers.

First, we estimated whether the night-time light in the border area increased by comparing the night-time light of each border area from 2013 to 2018. Second, by using the $t$-test to compare the night-time light of the border areas, the city centers, and the city as a whole, we judged the growth of border areas compared with the other areas, which addressed Hypothesis 1 . Third, this study used the ordinary least squares (OLS) regression model and a spatial econometric model to estimate location conditions on both sides of border areas, such as per capita GDP, urbanization rate, social insurance quota, and land price, to reveal the influencing factors behind the boundary growth, which addressed Hypothesis 2.

The Kwiatkowski-Philips-Schmidt-Shin (KPSS) test [37] and Ljung-Box test [38] were used to estimate the stationarity of the time-series night-time light data for the border areas, city centers, and cities as a whole. The stationarity test results are listed in Table 1 . As at least $80 \%$ of the study areas passed both tests, we believed the time-series night-time data were stationary.

Table 1. Stationarity test results for the time-series night-time light data.

\begin{tabular}{cccc}
\hline & Border Areas & City Centers & Prefectures \\
\hline Passing KPSS-test & 38 & 158 & 8 \\
Passing Ljung-Box-test & 47 & 189 & 9 \\
Total & 47 & 190 & 9 \\
\hline
\end{tabular}

\section{Results}

\subsection{Growth of Border Areas}

Figure 1a shows the geographical distributions of all border areas extracted using the methods discussed above. As the figure shows, most of the border areas grew during the study period, but the growth rate varied from region to region. First, the border areas that grew fast in the early years slowed down in growth. After the reform and opening up of border areas, with the large-scale participation of the Hong Kong capital in the economic activities of the Pearl River Delta and the formation of "front 
shop, back factory", the east corridor of Pearl River Delta, namely the Shenzhen-Dongguan-Guangzhou corridor, underwent rapid development [39]. This led to the development of border areas between these cities. The policy of urban integration between Guangzhou and Foshan has been carried out for 10 years, and the border areas between the two cities have also developed considerably. As a result, the border areas mentioned above grew more slowly during the study period. Second, some of the border areas that were undeveloped in the early years developed rapidly during the study period. For example, the north-western part of Guangzhou and the north-eastern part of Huizhou are now famous for their natural resources. However, in the early stage, there was a lack of industrialization and urbanization development motivation in these regions. Recently, forests and hot springs across borders in these regions have attracted tourists, and the shared tourist market has promoted the rapid growth of border areas.

(a)

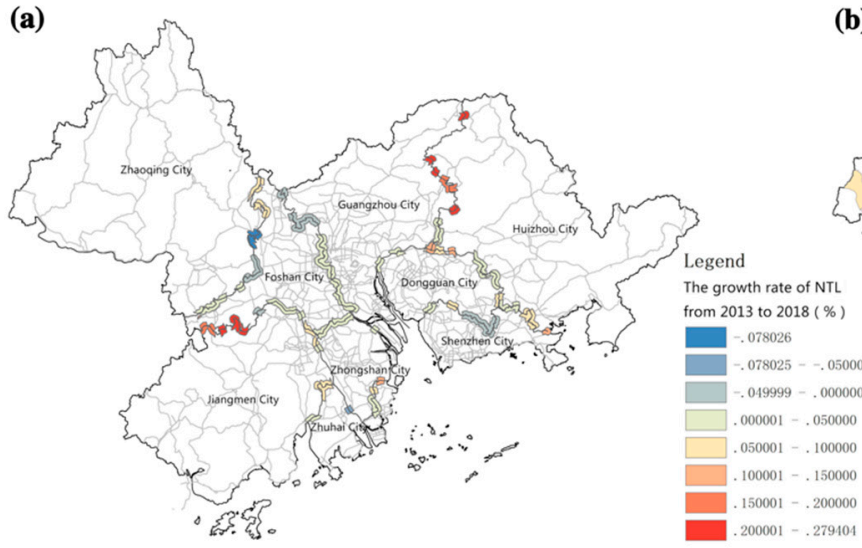

(b)

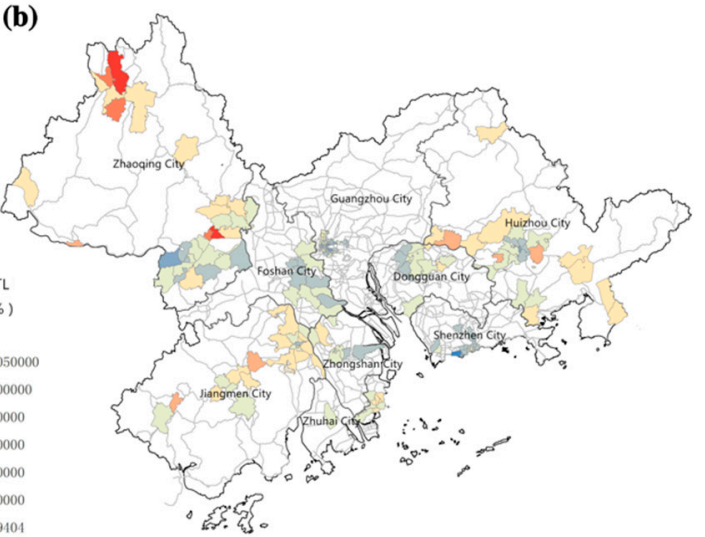

Figure 1. NTL growth rate across different regions. (a) The growth rate of NTL across all border areas.

(b) The growth rate of NTL across all city centers.

Figure $1 \mathrm{~b}$ shows the geographical distributions of all city centers extracted using the methods discussed above. As the figure shows, city centers with high urbanization and per-capita GDP rates, such as Dongguan, Shenzhen, Guangzhou, Foshan, Zhongshan, and Zhuhai, experienced relatively slow growth during the study period. On the contrary, city centers that were undeveloped in early years, such as Huizhou, Zhaoqing, and Jiangmen, developed rapidly during the study period.

The data in Figure 2 and Table 1 partially verify our first assumption that border areas developed faster than city centers. However, the comparison of the growth rate between the border areas and the city as a whole did not pass the t-test, even though the mean growth rate of the border areas was higher than the growth rate of prefectures.

Figure 2 also demonstrates that the city centers ranked in the top $10 \%$ grew at a substantially slower rate than other city centers. Most of the city centers ranked in the top 10\% were the old city centers that were the first areas in the city to develop. Most of the old city centers have become saturated, with no more space to develop, and the growth rate slowed down during the study period as a result. In this case, the cities that were seeking development space in the outskirts of the old city centers, where the city centers ranked in the top $20 \%$ and $30 \%$, have become important development areas.

In PRD, large numbers of new towns have emerged. Taking Guangzhou as an example, Guangzhou planned the Nansha New District in the south as a sub-center of the city and even established a China (Guangdong) Pilot Free Trade Zone there. In addition, the construction of Sino-Singapore Guangzhou Knowledge City in the north will be the key area for the development of new strategic industries in the city. A new transportation hub in the east that connects China's south-eastern areas is under construction. These new plans will bring rapid growth of areas outside the city center, which will drive the growth of city as a whole. As we can see in Figure 2, the growth rate of the prefecture was faster than that of the city centers during the study period. 
In summary, the border areas in PRD developed faster than city centers and the city as a whole during the study period. The city as a whole developed faster than city centers. Moreover, city centers have entered a state of saturation, whereas border areas have become the new growth hotspots.

(a)

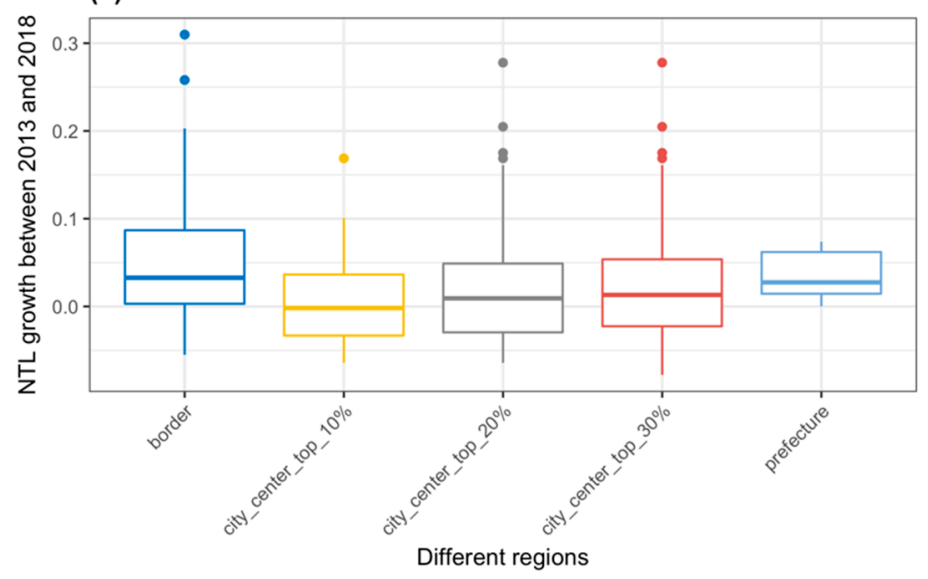

(b)

\begin{tabular}{|c|c|c|c|c|c|}
\hline & border & $\begin{array}{l}\text { city_center_top } \\
10 \%\end{array}$ & $\begin{array}{l}\text { city_center } \\
\text { _top_20\% }\end{array}$ & $\begin{array}{l}\text { city_center } \\
\text { top_30\% }\end{array}$ & prefecture \\
\hline $\begin{array}{l}\text { mean } \\
\text { growth }\end{array}$ & $5.71 \%$ & $0.42 \%$ & $1.62 \%$ & $1.95 \%$ & $3.37 \%$ \\
\hline \multicolumn{6}{|c|}{ p-value (Welch Two Sample t-test) } \\
\hline border & & $0.0001128 \cdots$ & $0.001827 \cdots$ & $0.003053 * *$ & 0.1246 \\
\hline $\begin{array}{l}\text { city_center } \\
\text { _top_10\% }\end{array}$ & & & 0.1274 & $0.0319^{*}$ & $0.01864^{\circ}$ \\
\hline $\begin{array}{l}\text { city_center } \\
\text { top_20\% }\end{array}$ & & & & 0.604 & 0.1282 \\
\hline $\begin{array}{l}\text { city_center } \\
\text { _top_30\% }\end{array}$ & & & & & 0.1954 \\
\hline prefecture & & & & & \\
\hline
\end{tabular}

Figure 2. The growth of NTL across border areas, city centers, and prefectures. (a) The box plots compare the growth rate across five different regions. The areas of city_center_top_10\% were included in both city_center_top_20\% and city_center_top_30\%. Prefecture areas included areas of all city centers and also the remaining areas of the corresponding municipality. (b) The table shows the t-test results across different regions.

\subsection{The Location Effects}

Figure 3a shows that the starting levels of NTL significantly determined the growth rate of NTL. This phenomenon can be explained as a late-developing advantage. In order to reduce costs, many industrial firms in Shenzhen have relocated their manufacturing parts to neighbouring cities, such as the relocation of BYD Auto and Desay Electronics to Huizhou, and the relocation of China Electronics and Huawei terminals to Dongguan. Moreover, $90 \%$ of firms in the Dongjiang Science and Technology Park of Huizhou are originally from Shenzhen. Many household appliance firms in the southern part of Foshan have also moved to the northern part of Zhongshan because of rising costs. The relocation of firms has led to the growth of cities with late-developing advantages, such as Huizhou, Dongguan, and Zhongshan.

Differing location conditions across borders may have also influenced firm relocations. Figure $3 \mathrm{~b}$ depicts a clearly inverted U-shaped relationship between the growth rate and the difference in urbanization rate, showing that the urbanization rate was a proxy for the rent costs. To be more specific, the higher the urbanization rate, the higher the rent costs were. This was attributed to the fact that if two municipalities had differences in terms of rent costs, firms had no incentive to relocate. If the rent difference between two cities was significantly different, although relocation could save firms a lot, the areas with much lower rents or areas with much lower urbanization rates would often be accompanied by insufficient living facilities and transportation facilities, which reduced employee stability. In this case, firms did not choose to relocate. Only if the rents of the two municipalities differed by a certain level and the relocation destination had basic service facilities to retain employees did the firms have the motivation to relocate. That is to say, when the urbanization rate difference between two municipalities reached a certain level, the growth of border areas brought about by the firm relocation was most likely to occur.

Another critical location condition was wage difference, which could be proxied by the GDP per capita difference. As shown in Figure 3c, the effects were heterogeneous. Figure 3d shows an inverted U-shaped relationship between the growth rate and the difference in social security costs per capita, and the border areas grew when the difference in social security costs per capita in two municipalities 
reached 115 Yuan RMB or more. This could be explained by the fact that lower social security cost per capita was a crucial factor in attracting firm relocations.

(a)

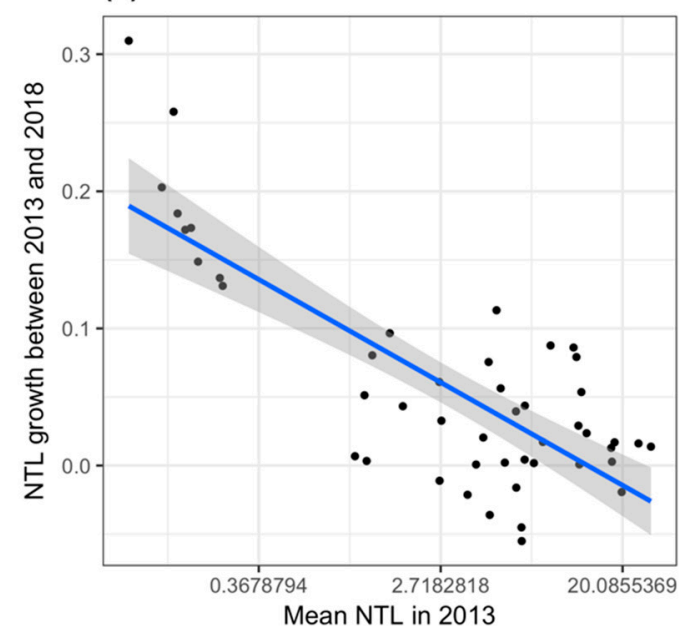

(c)

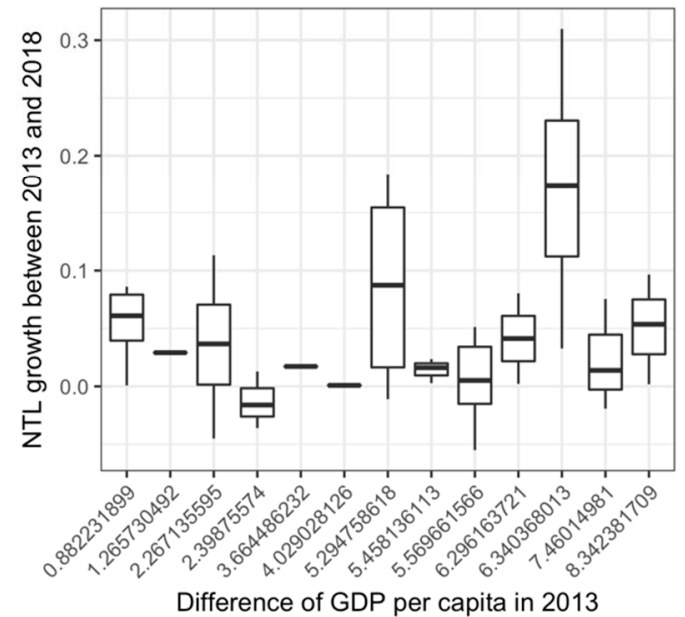

(b)

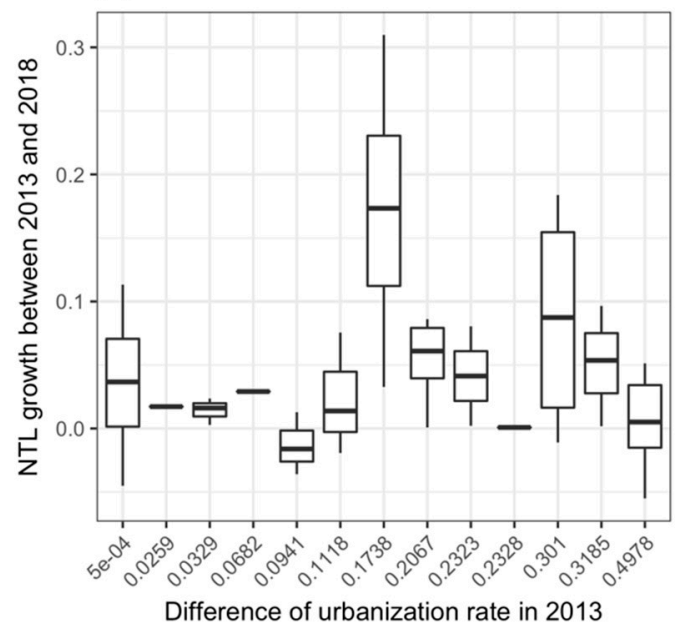

(d)

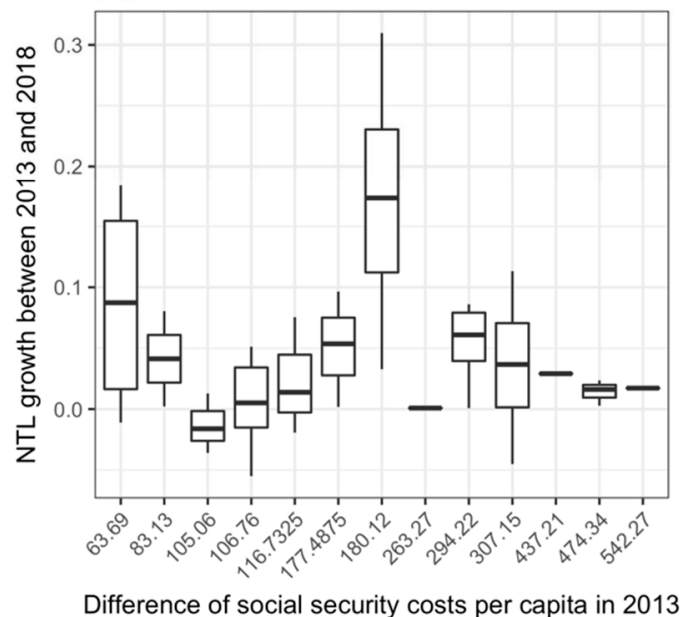

Figure 3. Growth rate of NTL versus the starting levels of NTL and different location conditions. (a) The scatterplot shows the strong relationship between the growth rate and the starting level of NTL in 2013. The brighter the border area, the more likely it was to grow slower in terms of NTL. (b), (c), and (d) show the relationships between the growth rate of NTL and the difference in location conditions between two municipalities across the border.

Based on the discussion above, all those factors on the growth of border areas could be estimated using the following equation:

$$
\text { Growth }_{\text {border }}=f\left(\begin{array}{c}
\log \left(\text { mean } N T L_{2013}\right), \text { urbanization rate }(\Delta), \\
\operatorname{GDP} \text { per capita }(\Delta), \text { social security costs }(\Delta), \varepsilon
\end{array}\right)
$$

In the baseline model (model (1) in Table 2), we found that the starting levels of NTL explained up to $61.2 \%$ of the variances in growth. When considering the starting levels of NTL and the GDP per capita factor simultaneously, we found the second order of the latter had positive effects on the growth rate, meaning that wage effects seemed to play out in the decisions of firm relocations. Model (3) considered the simultaneous effects of the starting levels of NTL, the GDP per capita, and also urbanization rate. We found that urbanization rate differences had negative effects on growth. However, model (4), which considered social security cost differences as an additive variable, outperformed all the previous 
models and achieved the highest explanatory powers at $78 \%$. The second degree of urbanization factor was estimated to negatively affect the growth rate, which aligned with our observation in Figure $3 b$, that is, the inverted U-shaped effects. Social security costs positively affected the growth, meaning it might be a critical factor of firm relocations. However, the effects of wage were not significant, whereas both social security costs and urbanization rate were considered. We interpreted this as the trade-off decision made by the firm owners. There might be fewer skilled workers in less-developed cities than the more-developed cohorts, so firms need to either compete against other newly relocated firms and also the local ones to recruit the skilled workers locally, or retain the workers from old locations. In both options, the firm might end up paying more for the skilled workers. However, it might pay less for low-skilled workers in the new location. In this regard, the wage factor can be ruled out, but the social security costs per capita become more critical, as firm needs to pay more for total wages if the numbers of workers are larger in the new location. Also, the urbanization rate could play out, as addressed above, as firms must ensure the living standards of workers retained from old locations. Therefore, we observed an inverted U-shaped effect of urbanization level. In models (1) and (2), we found the residuals exhibited strong spatial correlations (the Moran's I statistics were significant in both cases). This suggests that the process of economic convergence occurring in the border areas may be the spill over effect of each territory on its neighbours. Thus, we applied a spatial autoregressive model (SAR) in model (5) to estimate the effects of location conditions on the growth rate [40]. Model (5) exhibited similar behaviour to model (4), which reinforced our findings of model (4).

Table 2. Estimates of the effect of location conditions on the growth of border areas between 2013 and 2018.

\begin{tabular}{|c|c|c|c|c|c|}
\hline & \multicolumn{4}{|c|}{ Dependent Variable: } & \multirow[b]{3}{*}{ (5) } \\
\hline & \multicolumn{4}{|c|}{ Growth of NTL (in Percentages) } & \\
\hline & (1) & (2) & (3) & (4) & \\
\hline & \multicolumn{4}{|c|}{ OLS } & SAR \\
\hline Log (mean NTL in 2013) & $\begin{array}{c}-0.038^{* * *} \\
(0.004)\end{array}$ & $\begin{array}{c}-0.040^{* * *} \\
(0.005)\end{array}$ & $\begin{array}{c}-0.042^{* * *} \\
(0.004)\end{array}$ & $\begin{array}{c}-0.041^{* * *} \\
(0.005)\end{array}$ & $\begin{array}{c}-0.036^{* * *} \\
(0.014)\end{array}$ \\
\hline GDP per capita difference & & $\begin{array}{l}-0.012 \\
(0.050)\end{array}$ & $\begin{array}{c}0.034 \\
(0.045)\end{array}$ & $\begin{array}{c}0.070 \\
(0.048)\end{array}$ & $\begin{array}{c}0.051 \\
(0.035)\end{array}$ \\
\hline GDP per capita difference ${ }^{2}$ & & $\begin{array}{c}0.110^{* *} \\
(0.050)\end{array}$ & $\begin{array}{l}0.080^{*} \\
(0.047)\end{array}$ & $\begin{array}{c}0.016 \\
(0.061)\end{array}$ & $\begin{array}{l}-0.018 \\
(0.034)\end{array}$ \\
\hline Urbanization rate difference & & & $\begin{array}{c}-0.177^{* * *} \\
(0.046)\end{array}$ & $\begin{array}{c}-0.116^{* *} \\
(0.055)\end{array}$ & $\begin{array}{c}-0.111 \text { ** } \\
(0.034)\end{array}$ \\
\hline Urbanization rate difference ${ }^{2}$ & & & $\begin{array}{l}-0.056 \\
(0.048)\end{array}$ & $\begin{array}{c}-0.103 * \\
(0.052)\end{array}$ & $\begin{array}{c}-0.114^{* * * *} \\
(0.033)\end{array}$ \\
\hline Social security cost difference & & & & $\begin{array}{l}0.116^{*} \\
(0.061)\end{array}$ & $\begin{array}{c}0.137^{* * * *} \\
(0.047)\end{array}$ \\
\hline Social security cost difference ${ }^{2}$ & & & & $\begin{array}{l}-0.067 \\
(0.054)\end{array}$ & $\begin{array}{l}-0.031 \\
(0.039)\end{array}$ \\
\hline Constant & $\begin{array}{c}0.098^{* * *} \\
(0.009)\end{array}$ & $\begin{array}{c}0.101^{* * *} \\
(0.009)\end{array}$ & $\begin{array}{c}0.104^{* * *} \\
(0.008)\end{array}$ & $\begin{array}{c}0.102^{* * * *} \\
(0.008)\end{array}$ & $\begin{array}{c}0.085^{* * *} \\
(0.014)\end{array}$ \\
\hline Observations & 47 & 47 & 47 & 47 & 47 \\
\hline $\mathrm{R}^{2}$ & 0.612 & 0.651 & 0.756 & 0.780 & \\
\hline Adjusted $\mathrm{R}^{2}$ & 0.603 & 0.627 & 0.727 & 0.741 & \\
\hline Residual Std. Error & $0.050(\mathrm{df}=45)$ & $0.048(\mathrm{df}=43)$ & $0.041(\mathrm{df}=41)$ & $0.040(\mathrm{df}=39)$ & \\
\hline F Statistic & $71.012^{* * *}(\mathrm{df}=1 ; 45)$ & $26.779^{* * *}(\mathrm{df}=3 ; 43)$ & $25.441^{* * *}(\mathrm{df}=5 ; 41)$ & $19.799 * * *(\mathrm{df}=7 ; 39)$ & \\
\hline AIC & -144.7795 & -145.7937 & -158.6153 & -159.518 & -162.7326 \\
\hline Moran's I for residuals & $0.353 * * *$ & $0.335^{* * *}$ & -0.015 & -0.107 & -0.068 \\
\hline
\end{tabular}

Note: ${ }^{*} p^{* *} p^{* * *} p<0.01$; df: degrees of freedom; AIC: Akaike's An Information Criterion.

\section{Discussion}

The results presented above prove our hypothesis about the rise of border areas in the context of regional integration. In addition, location conditions, such as the differences in urbanization levels and social security costs, played out significantly in the process. The border areas did not grow faster than the city as a whole, even though they nearly passed the t-test. However, we also realized that, through our urban planning practices, a large number of new towns emerged in other parts of the region in 
recent years. These towns may have contributed significantly to the growth of the city as a whole. In a future study, we will collect more research material on those new towns to study their effects on the integration process.

The location conditions we tested in this study were limited. It is conceivable that the industrial structure, rent cost levels, and consumer market preferences of the neighbouring cities could also impact the development of the border areas, as they have been shown to significantly affect the decisions of firm relocations. Therefore, another possible improvement of this study is to collect more location conditions data and test their effects on the growth of border areas.

Moreover, this study only used PRD as the study case. However, there are another 11 integrated regions in China, and they vary significantly in terms of economic development levels. Therefore, a study that includes all those regions could be of significance to determine if the rise of border areas is a universal phenomenon and to more thoroughly estimate the effects of all the location conditions.

Urban growth also accompanies urban shrinkage [9]. While border areas become the target of firm relocation, other parts of the city might experience shrinkage. Understanding to what extent those areas experience a decrease in terms of population and economic activities could be of great importance. Therefore, another direction of future study is to estimate which parts of the region experience shrinkage and to what extent location factors affect the process.

Developing countries have been using regional integration as the major policy to narrow gaps between them and the developed world. As a result, we might observe more integrated regions occurring within one regime in the coming years. However, empirical studies that have focused on the growth of the border areas between countries have not focused on the emerging growth at the city boundaries. Therefore, we believe this study could provide some useful insights for academics and policymakers. Although firms could enhance their competitiveness by migrating to the border areas, city governments should deploy corresponding policies to ensure the success of emerging geographical transitions, for example, by increasing the land supply dedicated to manufacturing and housing and investing over the long term in transportation infrastructure and public service facilities. Furthermore, the agglomeration of firms may lead to the formation of industrial clusters in border areas where environmental risks may be high but monitoring has been neglected. Therefore, governments should coordinate to ensure that living standards are not compromised during the transition process.

This study used night-time light data to monitor regional economic activities to overcome the data deficiency issues that commonly exist in developing counties, providing a useful example of investigating urban growth at the city scale.

Author Contributions: Conceptualization was done by M.L. and H.C.; methodology was done by M.L, Y.H., M.H., and H.C. Software was handled by Y.H. Validation was done by M.L, Y.H., M.H., and H.C. Formal analysis was done by M.L, Y.H., M.H., and H.C. Investigation was done by M.L, Y.H., M.H., and H.C. Resources were handled by M.L. Data curation was done by M.L. and Y.H. Writing and original draft preparation were done by M.L, Y.H., M.H., and H.C. Writing, reviewing, and editing were done by M.L, Y.H., M.H., and H.C. Visualization was done by M.L, Y.H., M.H., and H.C. Supervision was provided by M.L. and H.C. Project administration was done by M.L. and H.C. Lastly, funding acquisition was handled by M.L. and H.C.

Funding: This study was funded by the Commonwealth Scientific and Industrial Research Organization, Australia.

Conflicts of Interest: The authors declare no conflicts of interest.

\section{References}

1. Venables, A.J. Winners and losers from regional integration agreements. Econ. J. 2003, 113, 747-761. [CrossRef]

2. Duan, D.; Zhang, Y.; Chen, Y.; Du, D. Regional Integration in the Inter-City Technology Transfer System of the Yangtze River Delta, China. Sustainability 2019, 11, 2941. [CrossRef]

3. Jordaan, A.C. Regional integration in Africa versus higher levels of intra-Africa trade. Dev. S. Afr. 2014, 31, 515-534. [CrossRef]

4. Geyikdagi, N.V. Regional Integration in Central Asia. J. Asia Pac. Bus. 2005, 6, 61-74. [CrossRef] 
5. Kiggundu, M.N.; DeGhetto, K. Regional Integration: Review of the Management Literature and Implications for Theory, Policy, and Practice. Afr. J. Manag. 2015, 1, 303-332. [CrossRef]

6. Ndulu, B.J. Infrastructure, regional integration and growth in sub-Saharan Africa: Dealing with the disadvantages of geography and sovereign fragmentation. J. Afr. Econ. 2006, 15, 212-244. [CrossRef]

7. Boschma, R. Relatedness as driver of regional diversification: A research agenda. Reg. Stud. 2016, 51, 1-14. [CrossRef]

8. Noorbakhsh, F.; Paloni, A.; Youssef, A. Human Capital and FDI Inflows to Developing Countries: New Empirical Evidence. World Dev. 2001, 29, 1593-1610. [CrossRef]

9. Du, Z.; Li, X. Growth or shrinkage: New phenomena of regional development in the rapidly-urbanising Pearl River Delta. Acta Geogr. Sin. 2017, 72, 1800-1811.

10. Crane, B.; Albrecht, C.; Duffin, K.; Albrecht, C. China's special economic zones: An analysis of policy to reduce regional disparities. Reg. Stud. Reg. Sci. 2018, 5, 98-107. [CrossRef]

11. Chung, H. Unequal Regionalism: Regional Planning in China and England. Plan. Pract. Res. 2015, 30, 570-586. [CrossRef]

12. Liu, W.; Dunford, M.; Song, Z.; Chen, M. Urban-rural integration drives regional economic growth in Chongqing, Western China. Area Dev. Policy 2016, 1, 132-154. [CrossRef]

13. Yu, B.; Liu, M.; Zhu, L.; Gao, J.; Zeng, J. The Border Effect and The Development of Border Region Between Conurbations. Sci. Geogr. Sin. 2012, 32, 666-672.

14. Li, X.; Li, S.; Chen, H.; Lang, W. China's export evolution in the dynamic global product space from 2000 to 2011. Curr. Sci. 2019, 117, 470-479.

15. Van Houtum, H. The Development of Cross-Border Economic Relations, a Theoretical and Empirical Study of the Influence of the State Border on the Development of Cross-Border Economic Relations between Firms in Border Regions of the Netherlands and Belgium; Tilburg CentER: North Brabant, The Netherlands, 1998.

16. Pogacar, K.; Sitar, M. Dynamics of Cross-border Spatial Development A Case Study of the Maribor(SI)-Graz(A) Development Axis. Geod. Vestn. 2009, 3, 489-508.

17. Federal Ministry of Transport, Building and Urban Development. Initiative Group of German Regions in Cross-Border Functional Regions: Final Report of the Demonstration Project of Spatial Planning (MORO); European Commission: Brussels, Belgium, 2013.

18. Turnock, D. Cross-border cooperation: A major element in regional policy in East Central Europe. Scott. Geogr. J. 2002, 118, 19-40. [CrossRef]

19. Jung, W. Cross-border Planning in Europe-The Case of ULYSSES. In Proceedings of the Vortrag Gehalten auf AESOP Congress "Planning to Achieve Planning to Avoid: The Need for New Discourses and Practices in Spatial Development and Planning", Ankara, Turkey, 11-14 July 2012.

20. Dicken, P. Global Shift: Transforming the World Economy; Paul Chapman Publishing Ltd.: London, UK, 1998.

21. Holguin-veras, J.; Xu, N.; Levinson, S.H.; Mcknight, C.E.; Weiner, R.D.; Paaswell, R.E.; Ozbay, K.; Ozmen-ertekin, D. An Investigation on the Aggregate Behavior of Firm Relocations to New Jersey (1990-1999) and the Underlying Market Elasticities. Netw. Spat. Econ. 2005, 5, 293-331. [CrossRef]

22. Cao, $\mathrm{X}$; $\mathrm{Xu}$, J. Spatial heterogeneity analysis of regional economic development and driving factors in China's provincial border counties. Acta Geogr. Sin. 2018, 73, 1065-1075.

23. Camagni, R. Territorial Capital and Regional Development. In Handbook of Regional Growth and Development Theories; Capello, R., Nijkamp, P., Eds.; Edward Elgar: Cheltenham, UK, 2009; pp. 118-132.

24. European Commission. Territorial state and perspectives of the European Union. In Scoping Document and Summary of Political Messages; European Commission: Luxemburg City, Luxemburg, 2005.

25. Organisation for Economic Co-operation and Development (OECD). OECD Territorial Outlook; OECD Publishing: Paris, France, 2001.

26. Dodescu, A.; Botezat, E.A.; Constangioara, A.; Bolos, M.I. An Exploratory Analysis of the Territorial Capital and Economic Growth: Evidence from Romania. Econ. Comput. Econ. Cybern. Stud. Res. 2018, 52, 95-112.

27. Camagni, R.; Capello, R. Macroeconomic and Territorial Policies Regional Competitiveness: An EU Perspective. Reg. Sci. Policy Pract. 2010, 2, 1-19. [CrossRef]

28. Jona, G. Determinants of Hungarian Sub-Regions' Territorial Capital. Eur. Spat. Res. Policy 2015, 22, 101-119. [CrossRef] 
29. Brasili, C.; Saguatti, A.; Benni, F. The Impact of the Economic Crisis on the Territorial Capital of Italian Regions. In Proceedings of the ERSA Conference, Las Vegas, NV, USA, 21-25 August 2012; pp. 16-19. Available online: http://www-sre.wu.ac.at/ersa/ersaconfs/ersa12/e120821aFinal00646.pdf (accessed on 24 September 2016).

30. Hayter, R. The Dynamics of Industrial Location: The Factory, the Firm and the Production System; Wiley: Hoboken, NJ, USA, 1997.

31. Nielsen, I.; Economic review, S.R. Who bears the burden of employer compliance with social security contributions? Evidence from Chinese firm level data. China Econ. Rev. 2008, 19, 230-244. [CrossRef]

32. Elvidge, C.D.; Cinzano, P.; Pettit, D.R.; Arvesen, J.; Sutton, P.; Small, C.; Nemani, R.; Longcore, T.; Rich, C.; Safran, J.; et al. The Nightsat mission concept. Int. J. Remote Sens. 2007, 28, 2645-2670. [CrossRef]

33. Xu, K.; Chen, F.; Liu, X. The Truth of China Economic Growth:Evidence from Global Night-time Light Data. Econ. Res. J. 2015, 9, 17-29.

34. Cao, C.; Xiong, J.; Blonski, S.; Liu, Q.; Uprety, S.; Shao, X.; Bai, Y.; Weng, F. Suomi NPP VIIRS sensor data record verification, validation, and long-term performance monitoring. J. Geophys. Res. Atmos. 2013, 118, 11664-11678. [CrossRef]

35. Shi, K.; Yu, B.; Huang, Y.; Hu, Y.; Yin, B.; Chen, Z.; Chen, L.; Wu, J. Evaluating the ability of NPP-VIIRS nighttime light data to estimate the gross domestic product and the electric power consumption of China at multiple scales: A comparison with DMSPOLS data. Remote Sens. 2014, 6, 1705-1724. [CrossRef]

36. Shi, K.; Huang, C.; Yu, B.; Yin, B.; Huang, Y.; Wu, J. Evaluating of NPP-VIIS night-time light composite data for extracting built-up urban areas. Romote Sens. Lett. 2014, 5, 358-366. [CrossRef]

37. Kwiatkowski, D.; Phillips, P.C.; Schmidt, P.; Shin, Y. Testing the null hypothesis of stationarity against the alternative of a unit root: How sure are we that economic time series have a unit root? J. Econ. 1992, 54, 159-178. [CrossRef]

38. Ljung, G.M.; Box, G.E. On a measure of lack of fit in time series models. Biometrika 1978, 65, $297-303$. [CrossRef]

39. Xu, X.; Li, X. Review and preview of the urbanization in Pearl River Delta in the past 30 years of reform and opening up. Econ. Geogr. 2009, 29, 13-18.

40. Bivand, R.; Hauke, J.; Kossowski, T. Computing the J acobian in G aussian Spatial Autoregressive Models: An Illustrated Comparison of Available Methods. Geogr. Anal. 2013, 45, 150-179. [CrossRef] 